\title{
Optimizing Inventory for Chicken Egg Livestock Industry
}

\author{
Cherish Rikardo', Alfian Tan², Paulina K Ariningsih ${ }^{3}$ \\ 1,2,3) Faculty of Industrial Technology, Industrial Engineering Department, \\ Universitas Katolik Parahyangan \\ Jl. Ciumbuleuit no 94, Bandung 41041 \\ Email: cherish@unpar.ac.id, alfian@unpar.ac.id, paulina.ariningsih@unpar.ac.id
}

\begin{abstract}
This study is to give an alternative of an optimum inventory model for chicken egg livestock industry. The characteristic of the egg livestock industry is very unique; since the chicken breeding performance varies. In a particular span of time, the industry might have ameliorating and deteriorating characteristics. Some farmers nourish several generations at the same time. This study generates a mathematical model to optimize the length time between purchases of a chicken generation to get optimum cost by considering demand seasonality. This study is also generating the algorithm to find the optimum solution in a simple way. Future potential researches are also stated.
\end{abstract}

Keywords: Optimization, inventory, egg, chicken, ameliorating

\begin{abstract}
Abstrak
Penelitian ini membahas mengenai model persediaan untuk industri peternakan telur ayam. Karakteristik industri peternakan telur sangat unik; karena kinerja ayam petelur yang bervariasi. Dalam rentang waktu tertentu, industri telur ayam mengalami deteriorasi dan ameliorasi pada kemampuan ayam untuk bertelur. Beberapa peternak memelihara beberapa generasi ayam secara bersamaan. Penelitian ini menghasilkan model matematika untuk mengoptimalkan waktu antara pembelian generasi ayam untuk mendapatkan biaya persediaan yang optimal dengan mempertimbangkan permintaan musiman. Penelitian ini juga menghasilkan algoritma untuk menemukan solusi optimal dengan cara sederhana. Saran untuk penelitian selanjutnya juga diberikan dalam penelitian ini.
\end{abstract}

Kata kunci: Optimization, inventory, egg, chicken, ameliorating

\section{Introduction}

Chicken and chicken eggs are most popular poultry as protein resources. For household with low-medium economic status, chicken eggs especially become first priority and most affordable animal sourced protein. It contains almost all nutrition needed by our body, except vitamin C. Along with economic growth from 1983 - 2015, demand of chicken eggs increased by average $3.57 \%$ yearly and predicted to have an increment into $4.21 \%$ from 2015-2020. The production rate tries to catch up the demand therefore industry increases their capacity up to $22.4 \%$ from 2013 to 2017 even though, the number is only $5 \%$ from total poultry industry in Indonesia. However, the poultry industry still faces a difficulty on managing the oversupply and supply-demand information inaccuracy (Kompas, 2017). The oversupply problem can be resolved with the proper inventory management.
The inventory of chicken egg can be grouped into deteriorating and ameliorating inventory system at once. The ameliorating system is inventory system which its utility decreases along its holding time meanwhile the deteriorating system is inventory system which its utility increases along its holding time. The characteristic of ameliorating and deteriorating system of chicken eggs is as described in Figure 1.

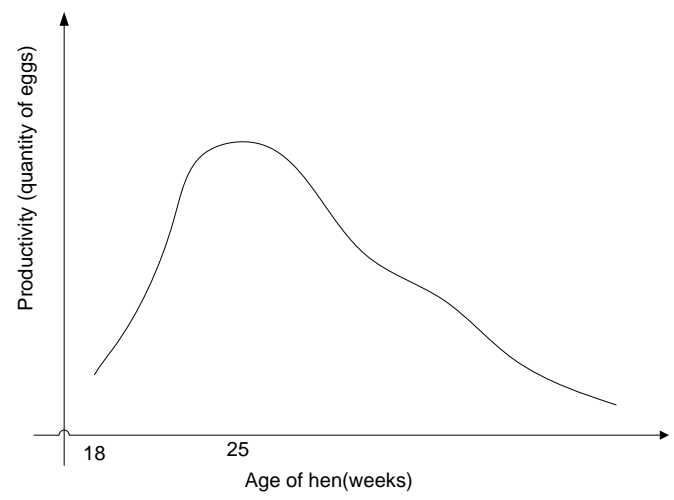

Figure 1. Productivity of hens 
As described in Figure 1, the ameliorating characteristic happens in the early age of the hen, when the hen laying rate is increasing. Farmer usually buy the hen when the hen is at 13-16 week of age. The hen will increase the laying rate until reaching age of 25 week. The ameliorating character also appears because of increasing value of carcass of the hen. A hen that is not laying eggs anymore, mostly 80 weeks old, can be sold. It is consumed as protein source. Its value is also increase because of the weight of the carcass. Meanwhile, the deteriorating happens when the hen laying rate is decreasing. To keep stability of egg inventory, many farmer raise chicken in several different generations. However, the supply may not fit with the demands because of death rate, illness, stress, and weather effects. Another deteriorating characteristic may happen because of cracking eggs. The cracking egg has shorter lifetime. However, the deteriorating characteristic has a very little influence compared the ameliorating characteristics.

The complexity of egg inventory system is increase because of the demand or consumption pattern. The demand of eggs is fluctuating seasonally. The peak season may happen during led Fithr or year end. Most reference has not discussed the effect seasonal demand towards ameliorating inventory.

Mondal et al and Wee et al stated that most literatures discuss about ameliorating and nondecaying inventory system, in contrary with the deteriorating characteristics. Hwang initiated the modeling with Weibull ameliorating system. Development of the model is continued with Hwang which model the deteriorating and ameliorating characteristics at one product. Mondal et al developed the ameliorating items for product which has demand characteristic that is not influenced by pricing. Meanwhile Wee et al developed model to solve ameliorating and deteriorating product with considering time value of money and also certain limited planning horizon. Chen developed the ameliorating and deteriorating inventory model for fresh agricultural item with ripeness considering piece dependent demand characteristics. Here, we may say that, in order to meet the characteristics of chicken egg industry, a new model shall be developed.

Therefore, this study is to model an egg inventory system for ameliorating character of hens considering demand seasonality. The end intention is to determine the optimum buying time between generation and also specific time to sell a particular generation. The strategy also considers feed cost, buying cost, and service level.

This study is reported in five sections. Reader will understand the background and research gap by reading introduction section. Second section is Methods which describes the methodology, research scope, assumptions and approaches of this study. Third section is Result and Discussion. It discusses the model development, simulation result of this study and managerial implication. Last section is Conclusions, a summary of this study which also describes the future potential research.

\section{Methods}

There are several steps conducted in this research to finally get a proper model for our research problem. They relate to a general method of system modeling. Detail of the methods can be explained by Figure 2 .

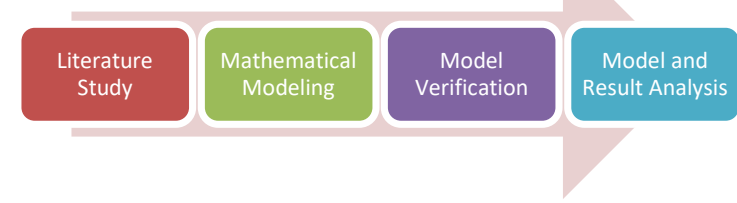

Figure 2. Research methodology

\section{Literature Study}

We perform a study literature on several publications or references that have the same problem direction. We have some studies about inventory system on ameliorating and deteriorating item. These include several different conditions that are probably faced by the decision maker, for instance there is a condition in which the pricing function is dependent on demand rate. We also get insight about ameliorating and deteriorating rate function commonly applied in the research.

\section{Mathematical Modeling}

We begin this modeling step with identifying the objective function which is to minimize total cost of an inventory system that can fulfill the egg demand in a year. This system consists of several events/components that have to be considered in the total cost function. The components will be a number of laying hens that has to be taken care for a certain period, a number of eggs that has to be preserved in the 
inventory, a purchasing cost that have to be bear for new chicken generation, and some revenue got from selling a group of nonproductive chicken. Based on problem characteristic, we determine 3 decision variables that will be considered in this research. They are new chicken generation repurchasing interval, the number of chicken purchased for each generation, and retention period of each chicken generation.

Some logical relationships between the decision variable and the cost component that become the basis for the total cost function development are

1. Assumed that we have a constant number of chickens in each purchasing, then the shorter the repurchasing interval is, the more frequently we buy a new group of chicken. More frequent purchasing will increase the total purchasing cost in a year. On the opposite, the frequency and the cost will decrease.

2. Assumed that we have $\mathrm{T}$ time unit of repurchasing interval, then the fewer the number of chicken purchased for each generation are, the smaller the purchasing cost will be. On the other hand, it will become larger.

3. Assumed that we have $\mathrm{T}$ time unit retention period, the larger the number of chickens for each generation we have, the greater the treatment/preservation cost will be (e.g. for the chicken feed)

4. Assumed that we have a constant number of chickens in each purchasing/for each generation, then the longer the retention period of a chicken generation is, the larger the total treatment cost will be.

5. The shorter the retention period of a specific generation of chicken is, the more frequent the chicken selling will be. This frequent selling will increase the revenue in a year.

6. Assumed that we have $T$ time unit retention period, then the smaller the number of chickens for each generation is, the smaller the revenue of chicken selling will be.

7. The bigger the number of chickens we have in our farm, the greater the number of eggs we will have in our inventory.
All these logical relationships will be developed in a mathematical model as a total cost function.

As previously explained, chicken performance which deals with the number of eggs produced is not constant. It depends on the chicken's age. Gathering some information from a chicken farmer in Bandung, we can estimate the characteristic of laying hens' performance according to its age. We can use Weibull function to model the characteristic.

The next component considered in this inventory problem is demand characteristic. According to the farmer, the demand of egg is relatively high on public holidays, especially on Hari Raya and Christmas. This behavior repeats every year. Therefore, we can conclude that it is a seasonal demand. We model this seasonal demand with a trigonometric function with time variable.

In this research we also consider a constraint that the demand has to be met by the inventory.

\section{Model Verification}

In the previous step, we try to translate the problem condition into an abstract mathematical realm. After completing the modeling, we have to make sure that the problem's logical relationship is correctly translated into the mathematical function. Then finally, we will apply our model into hypothetical problems so that we can be sure that this model can help us or the chicken farmer determine the optimal solution for their egg inventory. We will first develop several cases that will be based on a real farming condition. Solutions produced by solving the model will be investigated whether it makes sense or is practical enough for the problem we deal with. The discrepancy of the solution from real logical answer or expectation will be the basis for model correction.

\section{Model and Result Analysis}

We will analyze the problem behavior that is successfully modeled. The analysis will be based on the hypothetical cases developed and their solutions. We will try to investigate the effect of some changes in model's parameter, such as demand characteristic, chicken selling price, the laying hens' performance, and the chicken purchasing cost on the policy of inventory system. These parameters are known as the common changes that usually happen in the real condition. Demand characteristic, 
chicken selling price, and the chicken purchasing cost may change because the economic situation in a certain region. Chicken performance may change because the environment condition where they live. Sometimes in a rainy season that is full of storm and thunder, chicken could get stressed so that they cannot produce a usual number of eggs. In this step, we will also analyze some assumptions that we use in the model so that we can find some possible further developments for the model to fully capture the condition of egg inventory problem in the future.

\section{Mathematical Modeling}

This section explained the mathematical model developed based on the research problem condition. This section will be divided into 2 parts which are the list of nomenclature and the mathematical model for the inventory problem.

\section{Nomenclature}

Here is below the list of variable and function we use on the mathematical model:

$I(t) \quad=$ the number of egg inventory at time $\mathrm{t}$ (unit)

$\gamma=$ proportion of living hens during the retention period

$u^{0} \quad=$ the chicken age when it was bought (week)

$u_{i}(t) \quad=$ age of the $\mathrm{i}^{\text {th }}$ generation of chicken at time $\mathrm{t}$

$n_{i} \quad=$ the number of chicken we have for the ith generation of hens

$C\left(u_{i}\right) \quad=$ laying hens performance at its certain age $\left(u_{i}\right)$

(the number of eggs which may be produced by the chicken at time $\mathrm{t}$ )

$D(t) \quad=$ the number of egg demand at time $\mathrm{t}$ (unit)

$H \quad$ = inventory cost/egg/week

$P \quad=$ purchasing cost per laying hen

$K=$ = treatment cost per chicken during its retention period

$z \quad=$ selling price for a non-productive chicken

$T=$ retention period of one chicken generation (week)

$\tau=$ time interval between laying hens purchasing (week)

$\mathrm{TH}=$ the time horizon of inventory system analysis (week)

\section{Mathematical Model}

Based on interview to owner of a chicken poultry, it is identified that the demand of eggs is fluctuating seasonally. The demand of eggs would increase during holidays such as: led Fithr, end of year holiday or Chinese New Year. One mathematical function that represents seasonality is trigonometric functions.

To model the problem we firstly define the formula that represents a seasonal demand of egg at time $t$ as below.

$D(t)=A \sin \left(\omega\left(t+t_{1}\right)\right)+B \quad ; \mathrm{t}>0$

With $A, \omega, t_{1}$, and $B$ is the parameter of the function that will determine the demand characteristic.

The chicken will produce a certain number of eggs that depends on their age $\left(u_{i}\right)$. A hen may lay its eggs in the age of 18-19 weeks. The number of eggs laid by the hen would increase with the hen's age until it reaches its optimum productivity age. After reaching this period, the number of egg laid by a hen would decrease.

We use a Weibull function to approach the characteristic of hen's performance as in Fig 1. Here is below the function of chicken performances.

$C\left(u_{i}\right)=\frac{C \beta}{\delta}\left(\frac{u_{i}-t_{0}}{\delta}\right)^{\beta-1} e^{-\left(\frac{u_{i}-t_{0}}{\delta}\right)^{\beta}} \quad ; \mathrm{ui}_{\mathrm{i}}>\mathrm{t}_{0}$

The term $\mathrm{C}, \beta, \delta, t_{0}$ are respectively the parameter of Weibull performance function.

While the inventory system is running for a certain time horizon, the age of hen will increase and affect its laying performance. Therefore, the age of a certain chicken generation (i) will be a function of time $(\mathrm{t})$ at a certain time horizon. We define this chicken age function as below

$$
u_{i}(t)=t-i \tau+u^{0} \quad ; \mathrm{t}>0
$$

$u^{0}$ is a parameter that should be determined by the farmer and the value will be at least $t_{0}$.

Our decision on the number of chicken to retain, the purchasing interval, and the retention period will result in a number of eggs that is available in our inventory. During the time horizon, there will also be some changes on the number of inventory that depends on the productivity of our hens and the number of demand. The inventory changing at $t$ is the different between eggs laid from laying hen and 
demand of eggs during $t$, mathematically we define this inventory changes through formula (4).

$$
\frac{d I(t)}{d t}=\left(\gamma \sum_{i=0}^{\left[\frac{T H}{\tau}\right]} n_{i} C\left(u_{i}\right)\right)-D(t)
$$

for $i \tau \leq t \leq i \tau+T$

We perform an integration function for Eq. 4 by previously substituting some terms on this equation by its previous corresponding equation. The result will be Eq. 5 below.

$$
\begin{aligned}
& I(t)=\left(-\gamma \sum_{i=0}^{\left[\frac{T H}{\tau}\right]} n_{i} C e^{-\left(\frac{t-i \tau+u^{0}-t_{0}}{\delta}\right)^{\beta}}\right)+\frac{A}{\omega} \cos (\omega(t+ \\
& \left.\left.t_{1}\right)\right)-B t+\text { Constant }
\end{aligned}
$$

Running this inventory system will result in several kinds of cost that have to be minimized. These costs have previously described and will be defined in mathematical functions below.

Purchasing cost: for the price of the hen fledgling per unit is $\mathrm{P}$, if in one time of buying $n_{i}$ fledges the total cost of fledge purchase in an inventory horizon is:

\section{Purchasing cost}

$$
C_{\text {buy }}=P \sum_{i=0}^{\left[\frac{T H}{\tau}\right]} n_{i}
$$

Treatment cost: Supposed that each fledge would be cared until $T$ time, the proportion of chicken living until $T$ time is $\gamma$. If the feeding cost for each hen is constant, the total treatment of cost can be written as in Eq. 7 .

Treatment cost (feeding)

$$
C_{\text {food }}=K \gamma T \sum_{i=0}^{\left[\frac{T H}{\tau}\right]} n_{i}
$$

Inventory cost: Eggs laid by an i-th generation hen would be kept for $T$ weeks before being sold. If the holding cost for an egg is $H$, the total inventory cost for a period of holding is following Eq. 8

$$
\begin{aligned}
& \text { Inventory cost } \\
& C_{\text {hold }}=H \sum_{i=0}^{\left[\frac{T H}{\tau}\right]} \int_{i \tau}^{i \tau+T} I(t) d t \\
& \text { for } i \tau+T<T H
\end{aligned}
$$

The total inventory cost can be reduced by some revenue we get from the selling of unproductive chickens. This revenue can be defined as below

$$
R_{\text {sell }}=\gamma\left(-a T^{2}+b T+c\right) \sum_{i=0}^{\left\lfloor\frac{T H}{\tau}\right]} n_{i}
$$

We intentionally model the selling price as a quadratic function of $T$ because some logical consideration that the selling price of chicken will be differentiated by the age of the chicken. In real situation, we will not get the same price for selling an 8 week and a 60 week old chicken. The younger a hen's age o when it is sold, the cheaper its price. The older a hen, the more heavy a hen's weight would be. This will cause the hen's price would increase until a particular time, then the price of an old hen would be decreasing because the older the chicken, the worse its flesh quality. Demand of old hen would not sell well in the market.

To sum up, the objective function of this inventory system will be

Min Total Cost $=C_{\text {buy }}+C_{\text {food }}+C_{\text {hold }}-R_{\text {sell }}$

\section{Result and Discussion}

The model above is developed based on some real characteristics of chicken farm. A trigonometry function is an alternative function that is able to produce a cyclical or seasonal pattern. This characteristic will quite properly match the condition of egg demand pattern. Here is an example of demand function we try to build in order to describe the seasonal egg demand pattern in a year. The highest demand will happen in a holiday season. Some of the biggest holiday seasons in Indonesia are Christmas, New Year Holiday, and Idul Fitri. The number of eggs will be in a high demand at the end or the initial new year. Idul Fitri will be assumed to happen in the middle of the year. This condition can be well captured by the trigonometry equation as can be seen in $\mathrm{Eq} 11$.

A hypothetical case were developed to follow a condition where the medium sized poultry would like to fulfill demand of Bandung. Based on the interview with owner of medium sized chicken poultries, each week they are capable to handle $500 \mathrm{~kg}$ of eggs. When the weight of a chicken egg is estimated to be 0.05 $\mathrm{kg}, 500 \mathrm{~kg}$ of eggs consists of 10.000 pcs of eggs. The survey of Indonesia Statistics Biro (BPS) in 2015-2017, had revealed the average number of weekly eggs consumption in Indonesia is $2.014 \mathrm{~kg}$ per person. The number is equal to 40.28 pcs of eggs per week. We are then estimating the population of Bandung in 2018 by interpolating BPS data from previous year. The estimated figure is 2.5783 billion head. Based on the average weekly egg consumptions and Bandung population, it is estimated that the figure of egg consumption in 
Bandung is 103.85 billion of eggs. Supposed that the hypothetic demand which would like to be fulfilled by the medium sized poultry is assumed to be minimum $0.025 \%$ from the total consumption, the minimum demand of a medium sized poultry would be 25,963 eggs. This figure would be the bottom number of trigonometric function of demand function in Eq. 11.

$D(t)=1000 \sin (0.225(t+7))+25899$

Figure 3 shows the characteristic of demand represented by the equation.

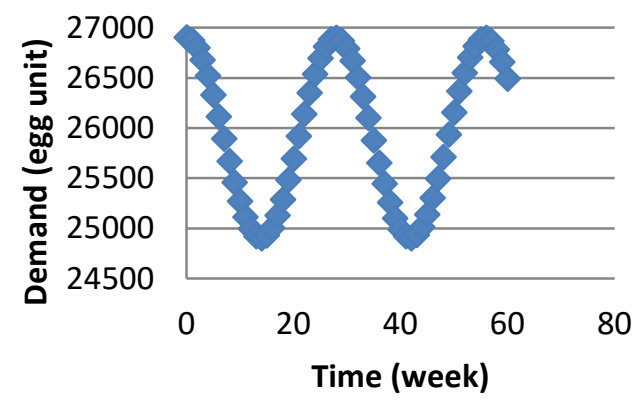

Figure 3. Demand characteristic

Figure 3 shows how the demand will increase when it is achieving the end of the year and the middle of the year (i.e. week 26-28).

Likewise, we also try to mimic the performance pattern of the laying hens. We realize that Weibull function can produce this performance characteristic. Here is an example of Weibull function that quite well capture the pattern.

$$
\begin{aligned}
& C\left(u_{i}\right)=\frac{700}{40}\left(\frac{u_{i}-5}{40}\right)^{2-1} e^{-\left(\frac{u_{i}-5}{40}\right)^{2}} \\
& \text { for } u_{i}>t_{0}
\end{aligned}
$$

Figure 4 shows how Eq. 12 can describe the performance pattern of hens.

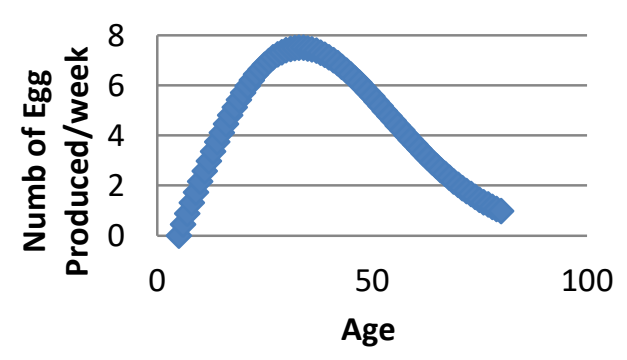

Figure 4. The example of performance pattern of hens
In Fig 4, we can see that the chicken will achieve its highest productivity at the age of 30 s week. We determine the parameter of this Weibull function based on some knowledge on real hens behavior.

The age of chicken will be the function of time in a time horizon because the age of chicken will increase continuosly since we bought it. Let's say that we start our analysis on $t=0$ and we buy every generation of chicken every 4 week for 2 week old hen. At $t=15$ the age of our second generation of chicken will be $15-1.4+2=13$ weeks old. The second generation of chicken will have an index of 1 for its generation because we buy the first generation at $t=0$ and the second one will be at time $0+1 \times \mathrm{T}$.

In modeling the changes in inventory number, we determine a limit for the time variable ( $t$ ) for every generation of chicken. It limits the analysis of every chicken performance and its influence to the inventory changes just as long as its retention period in the time horizon we use.

Defining the costing formula, we consider the period of our time horizon (TH). $\mathrm{T}$ will be a regular purchasing interval for a chicken generation of size $\mathrm{n}_{\mathrm{i}}$. Thus, the total purchasing cost will be the total number of chicken from all generation times the purchasing cost per chicken. The second type of cost is a treatment cost that may relate to feeding activity. The amount of cost will depend on how long someone retains a generation of chicken $(T)$ and it is assumed to be linearly correlated. The longer the time we retain our chicken, the higher the cost will be. In addition, this cost will also depend on how many chicken we retain and this factor will have the same kind of relationship with the retention period. However, not all the chicken will be counted in this function, because actually there will be a possibility that the chicken will die during the retention period. We accommodate this phenomenon with $\gamma$.

Calculating the inventory cost, we consider a unit inventory cost $(H)$ that usually deals with the facility cost we use (e.g. electricity, rental cost) and also maintenance cost. Just like we explained before, each generation of chicken will contribute to the changes of inventory number just for a certain period $T$ so that we can see its effect on the inventory cost function that has different limit for each generation of chicken. In conclusion, we can say that our mathematical model can accommodate most of 
the phenomena happening in the egg inventory system.

The implementation of this model can be done by simulation as described in Figure 5 . Here, we set the option of $\mathrm{T}$ that is feasible, then we generate several scenario of $\mathrm{T}$. The total cost shall be calculated for each combination of $T$ and $T$. The $T^{*}$ and $T^{*}$ are selected based on $T$ and $T$ which gives minimum total cost. The other parameter can be set based on the actual data find in the real business.

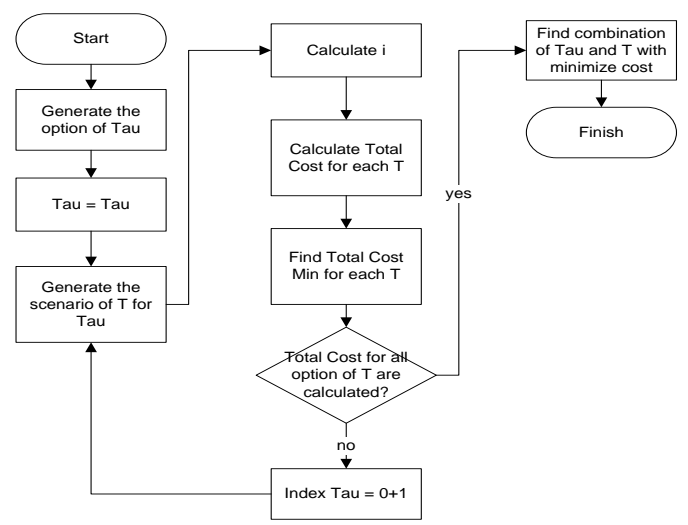

Figure 5. Algorithm to calculate minimum total cost

This research is limited by the approach of demand function, performance function and also revenue function. Detail parameter estimation of each function shall be investigated in deeper systematic research. Simplification for demand and revenue model can also decrease the accuracy of model performances. As we might find that the actual revenue function is quite unrealistic if it is approached with quadratic function, the more realistic revenue function can be more accurate with Weibull approach. Therefore, for near future, a research to improve the model can be conducted.

\section{Conclusion}

This paper had shown mathematical model and algorithm to find optimum time interval between purchase laying-hen, and the optimum retention period for each laying-hen generation. For near future, the model shall be implemented by real world data.

\section{Daftar Pustaka}

Mondal, B., Bhunia, A., and Maiti, M., "An Inventory System of Ameliorating Items for Price Dependent Demand Rate," Computers \& Industrial Engineering, vol. 45, p. 443456, 2003.

BPS, 2013. [Online]. Available: http://st2013.bps.go.id/dev2/index.php/site/t abel?tid $=51 \&$ wid $=0$. [Accessed 17 May 2018].

Direktorat Jendral Peternakan, "pertanian.go.id," 2016. [Online]. Available: http://www.pertanian.go.id/NAK-

2017fix/Prod_TelurAyamPetelur_Prop_201 7.pdf. [Accessed 17 May 2018].

Direktorat Jendral Peternakan, "pertanian.go.id," 2017. [Online]. Available: http://www.pertanian.go.id/NAK-

2017fix/Prod_TelurAyamBuras_Prop_2017. pdf. [Accessed 17 May 2018].

Kementrian Pertanian RI, Kementrian Kesehatan RI, "Litbang Pertanian," [Online]. Available:

http://nad.litbang.pertanian.go.id/ind/images /dokumen/budidaya/03-

Booklet\%20Telur.pdf. [Accessed 5 May 2017].

Wee, H.-M., Lo, S.-T., Yu J., and Chen, H., "An Inventory Model for Ameliorating and Deteriorating Items Taking Account of Time Value of Money and Finite Planning Horizon," International Journal of Systems Science, vol. 39, no. 8, pp. 801-807, 2008.

Hwang, H.-S., "Inventory Models for Both Deteriorating and Ameliorating Items," Computers \& Industrial Engineering, vol. 37, p. 257-260, 1999.

Hwang, H.-S., "A Study on An Inventory Model for Items with Weibull Ameliorating," Computers \& Industrial Engineering, vol. 33, p. 701-704, 1997.

Chen, J., "An Inventory Model for Ameliorating and Deteriorating Fresh Agricultural Items with Ripeness and Price Dependent Demand," International Conference of Information Technology, Computer Engineering and Management Sciences, 2011.

Kementrian Pertanian, "pertanian.go.id," Pusat Data dan Sistem Informasi Pertanian Sekretariat Jendral Kementrian Pertanian, 2016. [Online]. Available: http://epublikasi.setjen.pertanian.go.id/epub likasi/outlook/2016/Peternakan/OUTLOOK \%20TELUR\%202016/files/assets/common/ 
downloads/OUTLOOK\%20TELUR\%202016 .pdf. [Accessed 17 May 2018].

Tersin, R., Principles of Inventory and Materials Management 4th ed, New Jersey: PrenticeHall International, 1994.

Tadj, S., Sarhan, A., and El-Gohary, A., "Optimal Control of An Inventory System with Ameliorating and Deteriorating Items," Applied Sciences, vol. 10, pp. 243-255, 2008.

Kompas.com, 2017. [Online]. Available: https://regional.kompas.com/read/2017/04/ 18/00102481/industri.unggas.tanah.air.masi h.bermasalah. [Accessed 5 May 2018]. 